\title{
Analisa Cemaran Logam Berat (Pb, Cd, Zn) Pada Makanan Dan Minuman Kemasan Kaleng Dengan Menggunakan Metode Spektrofotometri Serapan Atom (SSA) \\ Baterun Kunsah $^{1}$, Nastiti Kartikorini ${ }^{1}$, Diah Ariana ${ }^{1}$ \\ ${ }^{1)}$ D3 Teknologi Laboratorium Medis FIK UMSurabaya Kunsah11980@gmail.com
}

\begin{abstract}
Tanggal Submit: 8 Maret 2021

Tanggal Review: 16 Maret 2021

Tanggal Publish Online: 18 Juni 2021

Makanan dan minuman yang dikemas dalam kaleng memiliki kemungkinan untuk terkontaminasi logam berat yang berasal dari komponen penyusun kaleng. Kontaminasi logam berat bisa menyebabkan keracunan dan berbahaya bila masuk ke dalam system metabolism tubuh dengan jumlah yang melebihi batas yang telah ditetapkan dalam SNI dan BPOM. Penelitian ini bertujuan untuk menganalisa Timbal $(\mathrm{Pb})$, Kadmium (Cd) dan seng (Zn) pada sarden, kornet, susu kaleng, sari buah, minuman berkarbonasi. pengambilan sampel dilakukan di dua lokasi berbeda yaitu pasar modern dan pasar tradisional, dengan tujuan agar dapat membandingkan perbedaan pada pasar modern dan pada pasar tradisional.Serapan logam diukur dengan menggunakan spektofotometri serapan atom (SSA) pada gelombang yang spesifik. Hasil penelitian adalah kadar cadmium (Cd) tidak teridentifikasi, kadar logam Timbal $(\mathrm{Pb})$ pada sampel makanan dan minuman kaleng adalah $0.01 \mathrm{mg} / \mathrm{kg}, 0.018 \mathrm{mg} / \mathrm{kg}, 0.026$ $\mathrm{mg} / \mathrm{kg}, 0.012 \mathrm{mg} / \mathrm{kg}, 0.027 \mathrm{mg} / \mathrm{kg}, 0.027 \mathrm{mg} / \mathrm{kg}, 0.018 \mathrm{mg} / \mathrm{kg}$, $0.015 \mathrm{mg} / \mathrm{kg}, 0.024 \mathrm{mg} / \mathrm{kg}$ dan $0.019 \mathrm{mg} / \mathrm{kg}$, sementara itu cemaran $\mathrm{Zn}$ adalah $0.188 \mathrm{mg} / \mathrm{kg}, 0.169 \mathrm{mg} / \mathrm{kg}, 0.193 \mathrm{mg} / \mathrm{kg}$, $0.184 \mathrm{mg} / \mathrm{kg}, 0.129 \mathrm{mg} / \mathrm{kg}, 0.105 \mathrm{mg} / \mathrm{kg}, 0.107 \mathrm{mg} / \mathrm{kg}, 0.098$ $\mathrm{mg} / \mathrm{kg}, 0.176 \mathrm{mg} / \mathrm{kg}, 0.152 \mathrm{mg} / \mathrm{kg}$. Semua sampel makanan dan minuman kaleng tidak ada yang melebihi batas maksimum cemaran yang telah di tetap kan dalam SNI dan Badan Pengawas Obat dan Makanan. Kadar cemaran logam berat $\mathrm{Pb}$ dan $\mathrm{Zn}$ pada sampel makanan dan minuman kaleng dari pasar tradisional lebih tinggi daripada sampel makanan dan minuman kaleng dari pasar modern
\end{abstract}

Kata kunci : Makanan-Minuman Kemasan Kaleng, SSA, Timbal, kadmium, seng

\section{PENDAHULUAN}

Perkembangan teknologi bidang pangan membuat tampilan dan kemasan produk pangan semakin bervariasi dengan tujuan untuk menarik konsumen untuk membeli produk tersebut. . Saat ini kemasan kaleng pada makanan dan minuman mendominasi pasaran tidak hanya pada pasar modern tetapi juga banyak dijumpai pada pasar tradisional. 
Berdasarkan pada data BPS 2018 menunjukkan bahwa konsumsi makanan dan minuman

bentuk jadi/olahan/kemasan mengalami kenaikan dua kali lipat ditahun 2019. Di Indonesia, makanan kaleng yang paling diminati diantaranya adalah sarden dan kornet kaleng, sedangkan minuman kaleng yang paling digemari diantaranya adalah susu kaleng (susu kental manis), sari buah dan minuman berkarbonasi (liputan 6,2020), Konsumen lebih tertarik untuk membeli makan dan minuman dalam kemasan kaleng karena lebih praktis, memiliki harga yang relative terjangkau, mudah untuk didapatkan dan memiliki daya tahan yang tinggi. Pengemasan produk pangan merupakan hal yang sangat penting dilakukan untuk menjamin kualitas dari bahan pangan.

Kemasan yang rusak bisa menyebabkan efek yang berbahaya seperti keracunan, bentuk kerusakan yang terjadi antara lain kerusakan fisik (kerusakan karena benturan keras) yang pada umumnya tidak secara langsung membahayakan konsumen. Selanjutnya kerusakan kimia berupa kerusakan yang terjadi karena reaksi kimia yang berlangsung di dalam bahan makanan berupa penurunan $\mathrm{pH}$, reaksi reduksi dan oksidasi. Hal tersebut disebabkan penggunaan jenis bahan kaleng yang tidak sesuai untuk makanan/minuman tertentu sehingga memicu terjadinya reaksi kimia antara kaleng dengan makanan/minuman. Kerusakan kimia yang sering terjadi pada makanan/minuman kaleng antara lain kaleng terjadi pengaratan pada kaleng, terbentuknya warna hitam, pemudaran warna kaleng serta kaleng menjadi kembung akibat terbentuknya gas hidrogen. . Kerusakan mikrobiologi pada minuman kaleng dibedakan atas dua kelompok, yaitu kaleng menjadi kembung akibat Pembentukan gas, terutama hidrogen $\left(\mathrm{H}_{2}\right)$ dan Pembentukan gas, terutama hidrogen $\left(\mathrm{H}_{2}\right)$ dan karbon dioksida $\left(\mathrm{CO}_{2}\right)$ yang disebabkan oleh pertumbuhan berbagai spesies bakteri pembentuk spora yang bersifat anaerobik yang tergolong Clostridium, termasuk C. botulinum yang memproduksi racun yang sangat mematikan. Kaleng tetap terlihat normal yaitu tidak kembung karena Tidak terbentuk gas,kerusakan semacam ini adalah Busuk asam yang disebabkan oleh pembentukan asam oleh beberapa bakteri pembentuk spora yang tergolong Bacillus, Busuk sulfida yang disebabkan oleh pertumbuhan bakteri pembentuk spora yang memecah protein dan menghasilkan hidrogen sulfida (H2S) sehingga makanan kaleng menjadi busuk dan berwarna hitam karena reaksi antara sulfida dengan besi. Pada minuman kaleng, masalah yang sering 
dijumpai dalam kemasan kaleng itu sendiri adalah adanya korosi, faktor yang mempengaruhi besarnya korosi pada kaleng bagian dalam yaitu, tingkat sisa oksigen dalam makanan, Adanya akselator korosi seperti nitrat dan senyawa sulfur lainnya, $\mathrm{pH}$ minuman dalam kaleng, Suhu dan lama penyimpanan, dan jenis kaleng dan lapisan penahan korosi (Perdana WW, 2019)

Kaleng yang terbuat dari logam atau campuran logam jelas bukan merupakan bahan yang inert, sehingga kemungkinan dapat bereaksi dengan isi kaleng dan melepaskan unsur unsur logam ke dalam makanan dan minuman yang di kalengkan. Dari unsur yang dilepaskan kemungkinan terdapat logam berat seperti Timbal $(\mathrm{Pb})$, Besi $(\mathrm{Fe})$, Timah (Sn) , Kadmium (Cd) ,dan seng (Zn) yang dapat mengganggu kesehatan. Adanya logam tersebut, walaupun dengan kadar kecil akan membahayakan kesehatan konsumen dan mengingat logam berat akan tertimbun di dalam tubuh, sehingga lambat laun kadarnya akan meningkat dan sangat membahayakan kesehatan (Sugiastuti et $a l, 2006$ ).

Berdasarkan penelitian yang dilakukan oleh Rasyid dkk (2013) terhadap kandungan logam timbal pada sampel susu kental manis kemasan kaleng menggunakan Spektrofotometri
Serapan Atom, terdapat dua sampel susu kental manis yang tidak memenuhi syarat yang ditetapkan oleh Peraturan BPOM RI NO. 03725/B/SK/VII/89 dengan konsentrasi $\mathrm{Pb}$ sebesar 0,1434 dan 0,1436. Menurut Novita dkk (2019) ditemukan adanya kandungan seng ( $\mathrm{Zn})$ pada margarin dalam kemasan kaleng dengan konsentrasi $\quad 0,792 \mathrm{mg} / \mathrm{kg}$ melebihi ambang batas yang sudah ditetapkan oleh SNI nomor 7387 tahun 2009 yaitu maksimal $0.1 \mathrm{mg} / \mathrm{kg}$. Tingkat kontaminasi logam berat yang tinggi dalam tubuh manusia yang dikonsumsi akan menyebabkan masalah kesehatan yang serius (Miskiyah, 2011). Berdasarkan latar belakang tersebut maka rumusan masalahnya adalah apakah logam berat $(\mathrm{Pb}, \mathrm{Cd}$ dan $\mathrm{Zn})$ bermigrasi terhadap makanan dan minuman kaleng didalamnya dan manakah logam berat $(\mathrm{Pb}, \mathrm{Cd}$ dan $\mathrm{Zn})$ yang paling banyak terkandung pada makanan dan minuman serta kaleng sarden, kornet, susu, sari buah dan karbonasi. Tujuan penelitian ini adalah untuk mengetahui ada atau tidaknya kandungan logam timbal $(\mathrm{Pb})$, cadmium (Cd), Zink (Zn) dan mengetahui besarnya kandungan logam berat timbal $(\mathrm{Pb})$, cadmium $(\mathrm{Cd})$, Zink (Zn) pada makanan dan minuman kaleng. Manfaat penelitian untuk mengetahui kandungan logam berat $(\mathrm{Pb} \mathrm{Cd}, \mathrm{Zn})$ pada makanan dan minuman kaleng yaitu sarden, 
kornet, susu, sari buah dan minuman berkarbonasi, berapa kadar kandungan logam berat $(\mathrm{Pb} \mathrm{Cd}, \mathrm{Zn})$ pada makanan dan minuman kaleng yaitu sarden, kornet, susu, sari buah dan minuman berkarbonasi memberikan informasi kepada masyarakat ataupun penelitian guna penelitian berikutnya.

\section{METODE PENELITIAN}

Penelitian ini merupakan penelitian deskriptif, dengan menggunakan rancangan acak kelompok yang ditunjukkan pada tabel 1 .

Table 1. rancangan acak kelompok

\begin{tabular}{|l|c|c|c|c|c|}
\hline \multirow{2}{*}{$\begin{array}{c}\text { Lokasi } \\
\text { pengam } \\
\text { bilan } \\
\text { sampel }\end{array}$} & \multicolumn{5}{|c|}{ Sampel } \\
\cline { 2 - 6 } & sarden & kornet & Susu & $\begin{array}{c}\text { Sari } \\
\text { buah }\end{array}$ & $\begin{array}{c}\text { Minum } \\
\text { an } \\
\text { berkar } \\
\text { bonasi }\end{array}$ \\
\hline $\begin{array}{l}\text { Pasar } \\
\text { tradisio } \\
\text { nal }\end{array}$ & A & B & C & D & E \\
\hline $\begin{array}{l}\text { Pasar } \\
\text { modern } \\
\text { (minim } \\
\text { arket) }\end{array}$ & F & G & H & I & J \\
\hline
\end{tabular}

Populasi dalam peneltian ini adalah sarden, kornet, susu, sari buah dan minuman berkarbonasi dalam kemasan kaleng yang dijual di pasar modern dan pasar tradisional wilayah Mulyosari Surabaya. Sampel dalam penelitian ini adalah makanan dan minuman kaleng yang diambil 3 macam makanan dan minuman kaleng pada Setiap toko. Jadi besar sampel seluruhnya adalah 30 sampel.
Pemeriksaan sampel dilakukan di Laboratorium Kesehatan Surabaya. Sampel merupakan makanan dan minuman kaleng dengan masa simpan baru $(<1$ tahun $)$.

Instrumen yang dipakai dalam penelitian ini adalah Spektrofotometri Serapan Atom, peralatan gelas laboratorium, neraca analitik, hot plate stirer, kertas saring Whatman no 42.

Bahan-bahan yang digunakan dalam penelitian ini adalah larutan standar $\mathrm{Pb}\left(\mathrm{NO}_{3}\right)_{2} \quad$ (Merk), larutan standar $\mathrm{CdCl}_{2} \cdot 2 \mathrm{H}_{2} \mathrm{O}$ (Merck), larutan standar $\mathrm{ZnSO}_{4}$ (Merk), larutan $\mathrm{HNO}_{3}$ 65\% (Merk), sarden, kornet, susu kental manis, minuman sari buah dan minuman berkarbonasi, aquades.

Proses Destruksi (Aminah dkk, 2017)

Preparasi sampel yaitu dengan cara ditimbang 10 gram sampel makanan dan minuman kaleng, dimasukkan ke dalam gelas kimia 100 mL ditambahkan $15 \mathrm{~mL}$ larutan $\mathrm{HNO}_{3}$ 65\% dan dipanaskan di atas hot plate pada suhu 2500C selama 16 jam. Setelah itu sampel di tanur pada suhu $300^{\circ} \mathrm{C}$ selama 4 jam. Kemudian hasil sampel yang sudah di tanur diencerkan dengan air suling hingga $50 \mathrm{~mL}$ ke dalam labu takar kemudian disaring menggunakan kertas saring Whatman. Filtrat yang diperoleh digunakan untuk analisis logam $\mathrm{Pb}, \mathrm{Cd}$ dan $\mathrm{Zn}$. 


\section{Pembuatan Kurva Standart}

Timbal (Pb)

Larutan standart $\mathrm{Pb}$ induk 1000 $\mathrm{mg} / \mathrm{L}$ dibuat dari larutan dengan merk dagang E-Merch. Larutan $\mathrm{Pb} 10 \mathrm{mg} / \mathrm{L}$ dibuat dengan cara memindahkan $2 \mathrm{~mL}$ larutan baku 1000 mg/L kdalam labu ukur $200 \mathrm{~mL}$ kemudian diencerkan sampai tanda batas. Larutan standart $\mathrm{Pb}$ 0,5 mg/L; $1 \mathrm{mg} / \mathrm{L}$; dan $5 \mathrm{mg} / \mathrm{L}$ dibuat dengan cara memindahkan $2,5 \mathrm{~mL} ; 5$ $\mathrm{mL}$; dan $25 \mathrm{~mL}$ larutan baku $10 \mathrm{mg} / \mathrm{L} \mathrm{ke}$ dalam labu ukur $50 \mathrm{~mL}$ kemudian diencerkan sampai tanda batas. Kemudian larutan tersebut dianalisis dengan spektrofotometri serapan atom bersamaan dengan sampel yang telah didestruksi untuk mengetahui konsentrasi logam $\mathrm{Pb}$ dalam sampel.

pembuatan kurva kalibrasi larutan standar Zn

Larutan stok Zn 1000 ppm dipipet sebanyak $5 \mathrm{~mL}$, diencerkan dengan $\mathrm{HNO} 365 \%$ hingga $50 \mathrm{~mL}$ didapatkan larutan standar Zn 100 ppm.

Kemudian dipipet $10 \mathrm{~mL}$ larutan standar Zn 100 ppm, diencerkan dengan HNO3 65\% hingga $100 \mathrm{~mL}$ didapatkan larutan standar Zn 10 ppm. Kemudian dibuat larutan standar logam Zn 0,05; 0,1; 0,2; 0,5; dan 1,0 ppm dan $20 \mathrm{ppm}$ yaitu dipipet masing - masing 0,$25 ; 0,5 ; 1$; 2,5; dan $5 \mathrm{~mL}$ larutan standar $10 \mathrm{ppm}$, diencerkan dengan HNO3 65\% hingga $50 \mathrm{~mL}$, sehingga diperoleh konsentrasi
0,$05 ; 0,1 ; 0,2 ; 0,5 ;$ dan $1,0 \mathrm{ppm}$ setelah itu diukur absorbansi larutan standar logam $\mathrm{Zn}$ pada panjang gelombang 213,9 $\mathrm{nm}$ menggunakan Spektrofotometri Serapan Atom. Kemudian Dibuat kurva kalibrasi larutan standar Zn dan hitung konsentrasi Zn pada larutan sampel.

\section{Pembuatan kurva kalibrasi larutan standar Cd}

Larutan stok Cd 1000 ppm dipipet sebanyak $5 \mathrm{~mL}$, diencerkan dengan $\mathrm{HNO} 365 \%$ hingga $50 \mathrm{~mL}$ didapatkan larutan standar Cd 100 ppm. Kemudian dipipet $10 \mathrm{~mL}$ larutan standar Cd 100 ppm, diencerkan dengan HNO3 65\% hingga $100 \mathrm{~mL}$ didapatkan larutan standar $\mathrm{Cd} 10 \mathrm{ppm}$. Kemudian dibuat larutan standar logam $\mathrm{Cd} 0,05 ; 0,1 ; 0,2$; 0,5; dan 1,0 ppm dan $20 \mathrm{ppm}$ yaitu dipipet masing - masing 0,$25 ; 0,5 ; 1$; 2,5; dan $5 \mathrm{~mL}$ larutan standar $10 \mathrm{ppm}$, diencerkan dengan $\mathrm{HNO} 365 \%$ hingga $50 \mathrm{~mL}$, sehingga diperoleh konsentrasi 0,$05 ; 0,1 ; 0,2 ; 0,5 ;$ dan 1,0 ppm setelah itu diukur absorbansi larutan standar logam $\mathrm{Cd}$ pada panjang gelombang 228,8 nm menggunakan Spektrofotometri Serapan Atom. Kemudian Dibuat kurva kalibrasi larutan standar $\mathrm{Cd}$ dan hitung konsentrasi $\mathrm{Cd}$ pada larutan sampel.

Pengolahan Data Teknik yang digunakan dalam analisis ini adalah metode kurva kalibrasi. Kurva standar, 
dimana terdapat hubungan Konsentrasi

(C) dengan Absorbansi (A). Maka nilai yang dapat di ketahui adalah nilai Slope dan Intersep. Kemudian nilai konsentrasi sampel dapat diketahui dengan memasukkan ke dalam persamaan regresi linear dengan menggunakan hukum LambertBeer yaitu: $Y=a x+b$

Keterangan: $\mathrm{Y}=$ Absorbansi Sampel $\mathrm{x}=$ Konsentrasi sampel $\mathrm{a}=$ Slope $\mathrm{b}=$ Intersep Dari perhitungan regresi linear, maka dapat diketahui kadar dari sampel dengan menggunakan rumus:

Kadar

$(\mathrm{mg} / \mathrm{kg})$

pembacaan sampel-pembacan blanko $\times 100$ Berat sampel

\section{HASIL DAN PEMBAHASAN}

Data hasil analisa didapatkan data seperti yang ditunjukkan dalam table 2

Table 2 Data konsentrasi PB, Cd, Zn pada sampel makanan dan minuman kaleng

\begin{tabular}{|c|c|c|c|c|c|c|c|c|}
\hline $\begin{array}{l}\text { Lokasi } \\
\text { Pengambilan }\end{array}$ & $\begin{array}{l}\text { Kode } \\
\text { sampel }\end{array}$ & $\begin{array}{l}\text { pengula } \\
\text { ngan }\end{array}$ & $\begin{array}{l}\text { Kadar } \\
\mathrm{Pb} \\
(\mathrm{mg} / \mathrm{k} \\
\mathrm{g})\end{array}$ & $\begin{array}{c}\text { Keteran } \\
\text { gan }\end{array}$ & $\begin{array}{l}\text { Kadar } \\
\mathrm{Cd} \\
(\mathrm{mg} / \mathrm{kg})\end{array}$ & Keterangan & $\begin{array}{l}\text { Kadar Zn } \\
(\mathrm{mg} / \mathrm{kg})\end{array}$ & $\begin{array}{c}\text { Keteran } \\
\text { gan }\end{array}$ \\
\hline \multirow{21}{*}{$\begin{array}{c}\text { Pasar } \\
\text { Tradisional }\end{array}$} & \multirow[t]{3}{*}{ A } & 1 & 0.0092 & MS & 0 & MS & 0.177 & MS \\
\hline & & 2 & 0.012 & MS & 0 & MS & 0.1598 & MS \\
\hline & & 3 & 0.0078 & MS & 0 & MS & 0.228 & MS \\
\hline & \multicolumn{2}{|c|}{ Rata-rata } & 0.010 & MS & 0 & MS & 0.188 & MS \\
\hline & \multicolumn{2}{|c|}{$\mathrm{Sd}$} & 0.002 & & 0 & MS & 0.035 & \\
\hline & \multirow{3}{*}{ B } & 1 & 0.017 & MS & 0 & MS & 0.167 & MS \\
\hline & & 2 & 0.012 & MS & 0 & MS & 0.173 & MS \\
\hline & & 3 & 0.049 & MS & 0 & MS & 0.238 & MS \\
\hline & \multicolumn{2}{|c|}{ Rata-rata } & 0.026 & MS & 0 & MS & 0.193 & MS \\
\hline & \multicolumn{2}{|c|}{$\mathrm{Sd}$} & 0.020 & & 0 & MS & 0.039 & \\
\hline & \multirow{3}{*}{$\mathrm{C}$} & 0.0092 & 0.0092 & MS & 0 & MS & 0.107 & MS \\
\hline & & 0.01 & 0.01 & MS & 0 & MS & 0.143 & MS \\
\hline & & 0.039 & 0.063 & MS & 0 & MS & 0.138 & MS \\
\hline & \multicolumn{2}{|c|}{ Rata-rata } & 0.019 & MS & 0 & MS & 0.129 & MS \\
\hline & \multicolumn{2}{|c|}{$\mathrm{Sd}$} & 0.017 & & 0 & MS & 0.020 & \\
\hline & \multirow[t]{3}{*}{ D } & 1 & 0.016 & MS & 0 & MS & 0.098 & MS \\
\hline & & 2 & 0.019 & MS & 0 & MS & 0.105 & MS \\
\hline & & 3 & 0.018 & MS & 0 & MS & 0.118 & MS \\
\hline & \multicolumn{2}{|c|}{ Rata-rata } & 0.018 & MS & 0 & MS & 0.107 & MS \\
\hline & \multicolumn{2}{|c|}{$\mathrm{Sd}$} & 0.002 & & 0 & MS & 0.010 & \\
\hline & $\mathrm{E}$ & 1 & 0.022 & MS & 0 & MS & 0.178 & MS \\
\hline
\end{tabular}




\begin{tabular}{|c|c|c|c|c|c|c|c|c|}
\hline & & 2 & 0.021 & MS & 0 & MS & 0.231 & MS \\
\hline & & 3 & 0.028 & MS & 0 & MS & 0.118 & MS \\
\hline & & & 0.024 & MS & 0 & MS & 0.176 & MS \\
\hline & & & 0.004 & & 0 & MS & 0.057 & \\
\hline & $\mathrm{F}$ & 1 & 0.025 & MS & 0 & MS & 0.157 & MS \\
\hline & & 2 & 0.017 & MS & 0 & MS & 0.141 & MS \\
\hline & & 3 & 0.013 & MS & 0 & MS & 0.209 & MS \\
\hline & & & 0.018 & MS & 0 & MS & 0.169 & MS \\
\hline & & & 0.006 & & 0 & MS & 0.036 & \\
\hline & $\mathrm{G}$ & 1 & 0.0087 & MS & 0 & MS & 0.167 & MS \\
\hline & & 2 & 0.019 & MS & 0 & MS & 0.173 & MS \\
\hline & & 3 & 0.0076 & MS & 0 & MS & 0.212 & MS \\
\hline & & & 0.012 & MS & 0 & MS & 0.184 & MS \\
\hline & & & 0.006 & & 0 & MS & 0.024 & \\
\hline $\begin{array}{l}\text { Pasar } \\
\text { Modern }\end{array}$ & $\mathrm{H}$ & 1 & 0.013 & MS & 0 & MS & 0.096 & MS \\
\hline & & 2 & 0.012 & MS & 0 & MS & 0.121 & MS \\
\hline & & 3 & 0.021 & TMS & 0 & MS & 0.098 & MS \\
\hline & & & 0.015 & MS & 0 & MS & 0.105 & MS \\
\hline & & & 0.005 & & 0 & MS & 0.014 & \\
\hline & I & 1 & 0.0092 & MS & 0 & MS & 0.073 & MS \\
\hline & & 2 & 0.016 & MS & 0 & MS & 0.093 & MS \\
\hline & & 3 & 0.021 & MS & 0 & MS & 0.127 & MS \\
\hline & & & 0.015 & MS & 0 & MS & 0.098 & MS \\
\hline & & & 0.006 & & 0 & MS & 0.027 & \\
\hline & $\mathrm{J}$ & 1 & 0.0092 & MS & 0 & MS & 0.163 & MS \\
\hline & & 2 & 0.017 & MS & 0 & MS & 0.187 & MS \\
\hline & & 3 & 0.032 & MS & 0 & MS & 0.107 & MS \\
\hline & & & 0.019 & MS & 0 & MS & 0.152 & MS \\
\hline & & & 0.012 & & 0 & MS & 0.041 & \\
\hline
\end{tabular}

Keterangan :

Referensi Persyaratan : *Standar Nasioal Indonesia7387:2009 : kadar Pb makanan olahan MS : Memenuhi Syarat $(<1 \mathrm{mg} / \mathrm{kg})$, TMS: Tidak Memenuhi Syarat $(>1 \mathrm{mg} / \mathrm{kg})$, minuman MS : Memenuhi Syarat $(<0,02 \mathrm{mg} / \mathrm{kg}), \quad$ TMS: Tidak Memenuhi Syarat $(>0,02$ $\mathrm{mg} / \mathrm{kg})$. kadar Cd makanan olahan MS : Memenuhi Syarat $(<1 \mathrm{mg} / \mathrm{kg})$, TMS: Tidak Memenuhi Syarat $(>1 \mathrm{mg} / \mathrm{kg})$, minuman MS : Memenuhi Syarat $(<0,03 \mathrm{mg} / \mathrm{kg})$, TMS: Tidak Memenuhi Syarat (>0,03 mg/kg). * BPOM RI. No. 03725/B/SK/VII/89 kadar Zn yaitu maksimal $40 \mathrm{mg} / \mathrm{Kg}(\mathrm{Zn})$

Dari hasil analisa tersebut teridentifikasi adanya kandungan logam berat pada sampel makanan dan minuman kaleng bisa disebabkan adanya migrasi logam-logam penyusun kaleng ke dalam produk, hal ini dapat disebabkan karena beberapa faktor, seperti $\mathrm{pH}$, waktu penyimpanan, suhu 
penyimpanan, Sisa oksigen dalam bahan pangan, dan beberapa faktor yang berasal dari bahan kemas (Perdana.WW, 2019)

\section{Timbal (Pb)}

Cemaran logam berat $\mathrm{Pb}$ teridentifikasi dalam sampel makanan dan miniman kaleng konsentrasi yang bervariasi dengan rata-rata konsentrasi $0.01 \mathrm{mg} / \mathrm{kg}$, $0.018 \mathrm{mg} / \mathrm{kg}, 0.026 \mathrm{mg} / \mathrm{kg}, 0.012 \mathrm{mg} / \mathrm{kg}$, $0.027 \mathrm{mg} / \mathrm{kg}, 0.027 \mathrm{mg} / \mathrm{kg}, 0.018 \mathrm{mg} / \mathrm{kg}$, $0.015 \mathrm{mg} / \mathrm{kg}, 0.024 \mathrm{mg} / \mathrm{kg}$ dan 0.019 $\mathrm{mg} / \mathrm{kg}$. dari data tersebut menunjukkan bahwa semua sampel makanan dan minuman kaleng mengandung cemaran $\mathrm{Pb}$, semua sampel tersebut masih memenuhi syarat SNI 7387:2009. Adanya cemaran $\mathrm{Pb}$ tersebut disebabkan Timbal $(\mathrm{Pb})$ merupakan salah satu logam berat yang terkandung dalam kemasan kaleng, keberadaan partikel $\mathrm{Pb}$ ini dapat berasal dari kaleng yang dilakukan pematrian pada proses penyambungan antara kedua bagian sisi dari tin plate untuk membentuk badan kaleng atau antara bagian badan kaleng dan tutupnya yang dipatri (Amin, 2015).

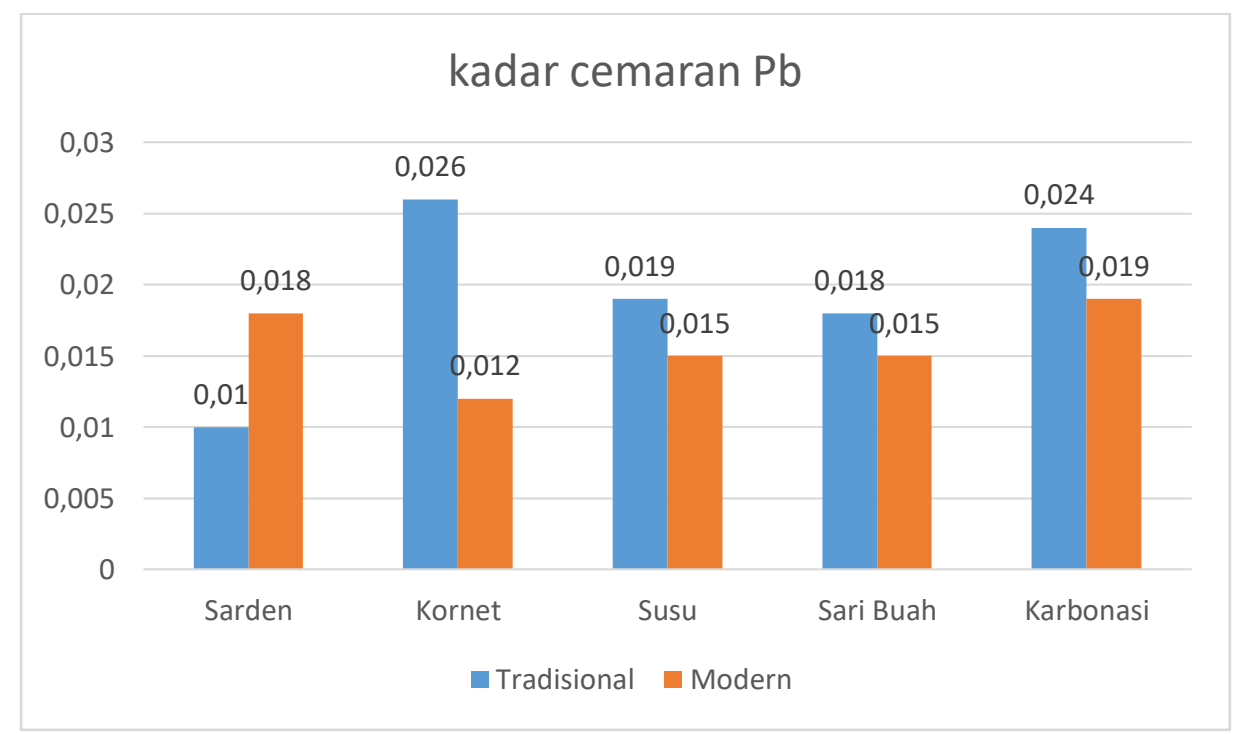

\section{Gambar 1 hasil analisis kadar cemaran $\mathrm{Pb}$ pada pasar tradisional dan pasar modern}

Berdasarkan gambar 1 tinggi dikarenakan Kemasan kaleng menunjukkan bahwa cemaran $\mathrm{Pb}$ yang melebihi stndar SNI 7387:2009 (> 0,02 $\mathrm{mg} / \mathrm{kg}$ ) adalah pada produk susu dan minuman berkarbonasi dengan termasuk jenis kemasan yang banyak digunakan dalam produk olah baik makanan atau minuman, Terjadinya konsentrasi berturut-turut $0,027 \mathrm{mg} / \mathrm{kg}$ korosi dalam produk pangan ada dan $0.024 \mathrm{mg} / \mathrm{kg}$. Pada jenis minuman kemungkinan dari logam dasar pembuat kaleng dan bahan pelapis kaleng , susu memiliki kadar cemaran $\mathrm{Pb}$ yang dimana logam tersebut kontak langsung 
dengan isi dari olahan produk susu. Selain itu packing kaleng yang kurang sempurna dapat menyebabkan korosi dan faktor dari kelembaban (Anggaraeni, AM, 2018). Jenis minuman karbonasi memiliki kadar logam $\mathrm{Pb}$ yang tinggi hal ini dikarenakan sifat minuman karbonasi yang dapat membentuk asam karbonat sehingga dapat membuat kaleng menjadi cepat korosi (Perdana, WW, 2019). Pada minuman karbonasi yang dijual pada pasar tradisional memiliki kadar cemaran $\mathrm{Pb}$ yang cenderung lebih tinggi dibandingkan yang dijual pada pasar modern dimungkinkan karena tempat penyimpanan minuman berkarbonasi yang lebih baik sehingga terhindar dari kelembapan.

\section{Cadmium (Cd)}

Data hasil analisis cemaran $\mathrm{Cd}$ pada sampel makanan dan minuman kaleng tidak teridentifikasi adanya cemaran $\mathrm{Cd}$ yang dimungkinkan karena konsentrasi cemaran $\mathrm{Cd}$ sangat kecil sehingga tidak teridentifikasi oleh alat. Sehingga dilihat dari sudut pandang kadar cemaran $\mathrm{Cd}$ seluruh sampel makanan dan minuman aman untuk di konsumsi

Seng (Zn)

Berdasarkan pada hasil analisis kadar cemaran Zn pada sampel makanan dan minuman kaleng didapatkan konsentrasi cemaran $\mathrm{Zn}$ yang bervariasi yaitu $0.188 \mathrm{mg} / \mathrm{kg}, 0.169 \mathrm{mg} / \mathrm{kg}, 0.193$ $\mathrm{mg} / \mathrm{kg}, 0.184 \mathrm{mg} / \mathrm{kg}, 0.129 \mathrm{mg} / \mathrm{kg}, 0.105$ $\mathrm{mg} / \mathrm{kg}, 0.107 \mathrm{mg} / \mathrm{kg}, 0.098 \mathrm{mg} / \mathrm{kg}, 0.176$ $\mathrm{mg} / \mathrm{kg}, 0.152 \mathrm{mg} / \mathrm{kg}$. semua konsentrasi dari cemaran $\mathrm{Zn}$ tersebut masih dibawah standar BPOM RI. No. 03725/B/SK/VII/89 sebesar $40 \mathrm{mg} / \mathrm{kg}$. adanya kontaminasi $\mathrm{Zn}$ pada makanan dan minuman kaleng dapat disebabkan karena adanya korosi pada bagian dinding makanan dan minuman kaleng. Korosi bisa terjadi karena jenis paduan logam penyusun kaleng tersebut dan homogenitas dalam pembuatan kaleng. Bila suatu paduan memiliki elemen paduan yang tidak homogen maka paduan logam tersebut akan memiliki karakteristik ketahanan korosi berbedabeda pada tiap bagiannya sehingga memungkinkan terjadinya korosi (Hellna.T, 2013). 


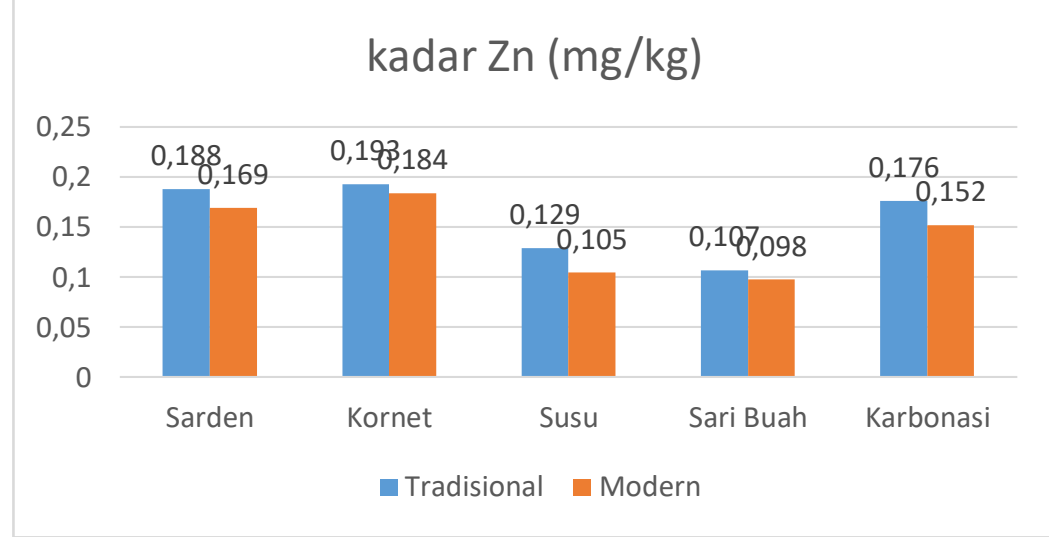

\section{Gambar 2. Hasil analisis kadar cemaran Zn pada pasar tradisional dan pasar modern}

Berdasarkan pada gambar 2 kadar cemaran $\mathrm{Zn}$ pada semua sampel makanan dan minuman kaleng yang dijual pada pasar tradisional memiliki konsentrasi yang lebih tinggi jika dibandingkan dengan yang dijual pada pasar modern. Hal tersebut dimungkinkan karena pada pasar tradisional kurang memperhitungkan mengenai kondisi penyimpanan yang berpengaruh terhadap kelembapan yang bisa menjadi salah satu penyebab terjadinya korosi pada bahan kaleng, sehingga bisa menyebabkan berpindahnya materi kaleng pada bahan makanan dan minuman.

\section{KESIMPULAN}

1. Tidak terdeteksi adanya cemaran $\mathrm{Cd}$ pada sampel makanan dan minuman kaleng, Terdeteksi adanya cemaran PB dan $\mathrm{Zn}$ pada sampel makanan dan minuman kaleng. Semua sampel masih memenuhi persyaratan SNI dan BPOM

2. Kadar logam Timbal $(\mathrm{Pb})$ pada sampel makanan dan minuman kaleng adalah $0.01 \mathrm{mg} / \mathrm{kg}, 0.018$ $\mathrm{mg} / \mathrm{kg}, \quad 0.026 \quad \mathrm{mg} / \mathrm{kg}, \quad 0.012$ $\mathrm{mg} / \mathrm{kg}, \quad 0.027 \mathrm{mg} / \mathrm{kg}, \quad 0.027$ $\mathrm{mg} / \mathrm{kg}, \quad 0.018 \quad \mathrm{mg} / \mathrm{kg}, \quad 0.015$ $\mathrm{mg} / \mathrm{kg}, 0.024 \mathrm{mg} / \mathrm{kg}$ dan 0.019 $\mathrm{mg} / \mathrm{kg}$, sementara itu cemaran $\mathrm{Zn}$ adalah $0.188 \mathrm{mg} / \mathrm{kg}, 0.169$ $\mathrm{mg} / \mathrm{kg}, \quad 0.193 \mathrm{mg} / \mathrm{kg}, \quad 0.184$ $\mathrm{mg} / \mathrm{kg}, \quad 0.129 \mathrm{mg} / \mathrm{kg}, \quad 0.105$ $\mathrm{mg} / \mathrm{kg}, \quad 0.107 \quad \mathrm{mg} / \mathrm{kg}, \quad 0.098$ $\mathrm{mg} / \mathrm{kg}, \quad 0.176 \quad \mathrm{mg} / \mathrm{kg}, \quad 0.152$ $\mathrm{mg} / \mathrm{kg}$. Semua sampel makanan dan minuman kaleng masih layak untuk dikonsumsi

3. Kadar cemaran logam berat $\mathrm{Pb}$ dan $\mathrm{Zn}$ pada sampel makanan dan minuman kaleng dari pasar tradisional lebih tinggi daripada sampel makanan dan minuman kaleng dari pasar modern. 


\section{DAFTAR PUSTAKA}

Aminah, Rahmawati, Naid T., Salma. (2017). Analisis Kadar Arsen (As) Dan Timbal (Pb) Pada Minyak Goreng Pemakaian Berulang Dengan Metode Spektrofotometri Serapan Atom. Jurnal Fakultas Farmasi Universitas Muslim Indonesia: Makassar

Amin, M., 2015. Penentuan Kadar Logam Timbal (Pb) Dalam Minuman Ringan Berkarbonasi Menggunakan Destruksi Basah Secara Spektroskopi Serapan Atom.Skripsi. Fakultas Sains dan Teknologi Universitas Islam Negri Maulana Malik Ibrahim Malang. Malang

Anggraini, AM. 2018. Analisis Kadar Logam Berat (Pb) Pada Berbagai Macam Susu Kaleng. Karya tulis Ilmiah. Fakultas Ilmu Kesehatan Universitas Muhammadiyah Surabaya. Surabaya

BPOM RI, 2009. Keputusan Kepala Badan Pengawas Obat dan Makanan Republik Indonesia Nomor HK.00.06.1.52.4011 Tentang Penetapan Batas Maksimum Cemaran Mikroba dan Kimia dalam Makanan. Jakarta

Hellna, T. (2013). Penentuan kandungan logam $\mathrm{Cd}$ dan $\mathrm{Cu}$ dalam produk ikan kemasan kaleng secara spektrofotometri serapan atom (SSA). Universitas Patimura, Ambon
Liputan

6.

2020.

https://hot.liputan6.com/read/41

93515/10-makanan-kaleng-siapsaji-terfavorit-praktis-dan-sehat diakses 11 November 2020

Miskiyah. 2011. Study Of Indonesian National Standard for liquid Milk in Indonesia. Jurnal Balai Besar Penelitiaan Dan Pengembangan Pasca Panen Pertanian 13 (1) : 1-7. : Bogor

Nofita,dkk. 2019. Penetapan Kadar Logam Timbal (Pb) Dan Seng (Zn) Pada Margarin Dengan Metode Spektrofotometri Serapan Atom. Jurnal Farmasi Malahayati Vol 2 No 1, 24 - 32

Perdana, WW. 2019. ANALISIS LOGAM BERAT DI KEMASAN KALENG, Agroscience Vol 9 No. 2 Tahun 2019. 215-223.

Rasyid, Roslinda, Humairah \& Zulharmitta, 2013. Analisis Kadmium (CD), Seng (Zn) dan Timbal (Pb) Pada Susu Kental Manis Kemasan Kaleng Secara Spektrofotometri Serapan Atom (SSA). Jurnal Farmasi Higea, Vol.5, No. 1

Standar Nasional Indonesia No. 7387:2009 Tentang Cemaran Berat dalam Makanan Kemasan

Sugiasti, S., Sediarso, \& Kharisma, L.W (2006). Analisis cemaran logam berat dalam buah Ananas Comusus (L.) Merr. Kaleng secara spektrofotometri serapan atom. Jurnal Ilmu Kefarmasian Indonesia,4,(2), 92-95. 